\title{
IDENTIFIKASI FASILITAS PEJALAN KAKI DI KOTA BANDAR LAMPUNG
}

\author{
Fera Lestari ${ }^{1}$, Galuh Pramita ${ }^{2}$, \\ Teknik Sipil Universitas Teknokrat Indonesia ${ }^{\mathbf{1 , 2}}$ \\ Fera_lestari@teknokrat.ac.id
}

\begin{abstract}
\begin{tabular}{lll}
\hline Received: (15 juni 2020) & Accepted: (6 Juli 2020) & Published : (30 Juli 2020)
\end{tabular}
There are around 273,000 pedestrians who died in road traffic accidents. This amount is equivalent to $22 \%$ of the total road traffic deaths. Pedestrians need special attention because pedestrians have the same rights as other road users who use vehicles. The high volume of pedestrians will lead to the provision of pedestrian facilities that are also in accordance with the number of pedestrians. The purpose of this study is to determine the need for pedestrian facilities in reducing the risks faced by pedestrians. The method used in this study is the Secondary Data Analysis method which is a research strategy that utilizes existing quantitative or qualitative data to find new problems or test the results of previous studies. It can be concluded that the facilities available in Bandar Lampung City currently cannot meet the need for pedestrians both pedestrian facilities in the form of sidewalks and crossing facilities in the form of crossing bridges, crossing tunnels and countdown signals at signal intersections. Pedestrian facilities that are currently available are still very minimal. Pedestrians still do not get comfort and safety when doing walking activities both crossing and walking on the side of the road
\end{abstract}

Keywords: Pedestrian, Secondary Data Analysis Sidewalks, Crossing Bridge,

\begin{abstract}
Abstrak
Pada tahun 2010 setiadaknya terdapat 273.000 pejalan kaki yang meninggal dunia dalam kecelakaan lalu lintas yang terjadi di jalan. Besarnya angka tersebut sebanding dengan $22 \%$ dari seluruh total kematian lalu lintas jalan. Pejalan kaki perlu mendapat perhatian khusus karena pejalan kaki memiliki hak yang sama dengan pengguna jalan lain yang menggunakan kendaraan. Jumlah pejalan kaki yang banyak menuntut adanya penyediaan fasilitas pejalan kaki sesuai dengan jumlah pejalan kaki yang ada. Penelitian ini mengidentifikasi kebutuhan akan fasilitas untuk para pejalan kaki yang dilakukan sebagai upaya dalam mengurangi resiko yang dihadapi oleh pejalan kaki. Metode yang digunakan dalam penelitian ini adalah analisis data sekunder. Analisis dilakukan dengan menggunakan data kuantiatif maupun kualitatif yang telah tersedia dari penelitian-penelitian yang telah dilakukan. Analisis menggunakan data-data sekunder ini dapat digunakan dalam menemukan permasalahan baru atau menguji hasil penelitian terdahulu. Dapat disimpulkan bahwa fasilitas yang diperuntukkan untuk pejalan kaki di Kota Bandar Lampung saat ini belum dapat memenuhi kebutuhan bagi pejalan kaki baik fasilitas pejalan kaki berupa trotoar maupun fasilitas penyebrangan berupa jembatan penyebrangan, terowongan penyebrangan dan countdown signal pada simpang bersinyal. Belum optimalnya penyediaan fasilitas untuk pejalan kaki menyebabkan keamanan dan kenyamanan bagi para pejalan kaki dalam melakukan aktivitas berjalan dan menyebrang belum dapat terpenuhi.
\end{abstract}

Kata Kunci: Pejalan Kaki ,Analisis Data Sekunder,Trotoar,Jembatan Penyebrangan. 
To cite this article:

Lestari. (2020). Identifikasi Fasilitas Pejalan Kaki Di Kota Bandar Lampung. Journal Of Infrastructural In Civil Engineering, Vol(1), 27-32

\section{PENDAHULUAN}

Sangat penting berjalan kaki yang berkeselamatan karena semua orang merupakan pejalan kaki. Berjalan merupakan moda transportasi dasar dan umum di semua masyarakat di seluruh dunia. Pengurangan atau peniadaan resiko - resiko yang dihadapi pejalan kaki merupakan sebuah tujuan kebijakan yang penting dan dapat dicapai. Terdapat hubungan yang erat antara lingkungan pejalan kaki dan pejalan kaki. Berjalan kaki di lingkungan yang kekurangan infrastruktur untuk pejalan kaki dan lingkungan pejalan kaki yang mengijinkan penggunaan kendaraan berkecepatan tinggi meningkatkan resiko cedera pejalan kaki. Resiko sebuah kendaraan bermotor menabrak pejalan kaki seiring bertambahnya jumlah kendaraan bermotor yang berinteraksi dengan pejalan kaki meningkat. Sebagian besar kecalakaan yang dialami oleh pejalan kaki terjadi saat pejalan kaki sedang melakukan aktivitas menyebrang jalan.

Secara garis besar kasus kecelakaan lalu lintas yang menyebabkan korban meninggal dunia ditaksir mencapai 273.000 di tahun 2010 (WHO, 2013). Besarnya angka tersebut sebanding dengan 22\% dari seluruh total kematian lalu lintas yang terjadi di jalan. Perbandingan pejalan kaki yang meninggal dunia dalam kecelakaan lalu lintas di jalan memiliki angka yang lebih tinggi di negara-negara yang berpenghasilan rendah dan menengah dibandingkan dengan negara-negara yang berpenghasilan tinggi. Penelitian yang telah dilakukan pada di tingkat kota menunjukan hasil yang memperkuat tentang tingginya angka mortalitas dalam kecelakaan lalu lintas yang terjadi di jaln terutama pada negara-negara yang memiliki penghasilan rendah dan menengah. Sebagai contoh di Kota Mumbai 78\% korban meninggal akibat kecelakaan lalu lintas adalah pejalan kaki. Sedangkan di Kota Delhi pejalan kaki yang menjadi korban meninggal dunia akibat kecelakaan lalu lintas sebesar 53\%.

Sebanyak kurang lebih $68 \%$ pejalan kaki meninggal karena ditabrak oleh kendaraan ketika pejalan kaki tersebut berada di tengah jalan (Damsere Derry J, et al,2010). Menurut informasi yang diberikan oleh 73 pejalan kaki yang menjadi partisipan penelitian di Kenya, $53(72,6 \%)$ mengalami cedera saat sedang menyeberang jalan, $8(11 \%)$ ketika sedang berdiri di tepi jalan, $6(8,2 \%)$ ketika sedang berjalan kaki di tepi jalan dan $6(8,2 \%)$ ketika sedang melakukan aktifitas lain, misalnya menjajakan makanan (WHO, 2013).

Meski kecelakaan pejalan kaki lebih banyak terjadi di perkotaan daripada di pedesaan di negara-negara berpenghasilan tinggi, hal sebaliknya justru terjadi di beberapa negara berpenghasilan rendah dan menengah. Sebagai contoh terdapat kurang lebih 70\% dari keseluruhan kematian pejalan kaki di Uni Eropa dan 76\% di Amerika Serikat terjadi di wilayah perkotaan. Sekitar 50\% dari total fatalitas yang terjadi di jalan adalah pejalan kaki. Pejalan kaki yang umumnya menjadi korban merupakan anak-anak dan lansia (Austroads, 1995). Kurang lebih sebesar $8 \%$ dari total kematian yang terjadi pada tahun 2004,2005 dan 2006 di Australia adalah dari pejalan kaki atau sekitar 32 kematian pejalan kaki. Tidak hanya itu korban dari pejalan kaki juga berkontribusi sebanyak $6 \%$ dari semua perawatan yang ada di rumah sakit atau sekitar 1.058 pasien.

Menurut Keputusan Direktorat Jendral Perhubungan Darat Nomer: SK.43/AJ007/DRJD/(\& pejalan kaki merupakan orang yang melakukan aktifitas berjalan kaki serta sebagai salah satu unsur pengguna jalan. Merujuk pada PP No. 45tahun 1993 Pejalan kaki wajib berjalan pada potongan atau bagian jalan yang disediakan bagi pejalan kaki atau pada bagian jalan sebelah kiri apabila tidak terdapat bagian jalan yang disediakan untuk pejalan kaki

Trotoar merupakan satu diantara yang ada dari pendukung fasilitas jalan yang terkadang disalahfungsikan. Mengacu pada Undang Undang Republik Indonesia Nomor 22 Tahun 2009 Tentang Lalu Lintas Dan Angkutan Jalan, Pasal 45 ayat (1) dinyatakan bahwasanya fasilitas pendukung penyelenggaraan lalu lintas serta angkutan jalan terdiri dari trotoar, lajur sepeda, tempat penyeberangan pejalan kaki, halte, dan/atau fasilitas khusus bagi penyandang cacat, dan manusia usia lanjut. Trotoar yang baik bagi pejalan kaki memiliki persyaratan yaitu memiliki jarak sekitar 1,8 meter hingga 2 meter di luar tempat parkir serta tempat pedagang berjualan dan juga fasilitas publik lainnya yang tidak seharusnya berada di trotoar. 
Selain dari trotoar, fasilitas lain yang diperuntukkan bagi pejalan kaki dan semestinya ada adalah fasilitas penyebrangan. Fasilitas penyebrangan ini dapat berupa fasilitas penyebrangan jalan sebidang seperti zebra cross dan juga dapat berupa jembatan atau terowongan penyebrangan. Tujuan dari penelitian ini adalah untuk mengetahui kebutuhan fasilitas pejalan kaki dalam mengurangi resiko yang dihadapi pejalan kaki.

\section{METODE PENELITIAN}

Metode yang digunakan dalam penelitian ini adalah analisis data sekunder. Metode ini dilakukan sebagai salah satu strategi dalam penelitian dengan cara mengumpulkan data - data yang yang dibutuhkan yang selanjutnya data- data tersebut akan dianalisis sehingga menghasilkan suatu data atau kesimpulan baru. Analisis dilakukan dengan menggunakan data kuantiatif maupun kualitatif yang telah tersedia dari penelitian-penelitian yang telah dilakukan. Analisis menggunakan data-data sekunder ini dapat digunakan dalam menemukan permasalahan baru atau menguji hasil penelitian terdahulu.

\section{HASIL DAN PEMBAHASAN}

\section{Pejalan Kaki di Kota Bandar Lampung}

Pejalan kaki perlu mendapat perhatian khusus karena pejalan kaki memiliki hak yang sama dengan pengguna jalan lain yang menggunakan kendaraan. Kebutuhan akan fasilitas yang disediakan khusus untuk pejalan kaki akan tercipta akibat adanya permintaan pejalan kaki. Permintaan pejalan kaki ini dapat dilihat dari berapa banyak volume atau jumlah dari pejalan kaki yang ada pada suatu ruas jalan. Tingginya volume pejalan kaki berpotensi menimbulkan adanya penyediaan fasilitas pejalan kaki yang tentunya disesuaikan dengan jumlah pejalan kaki yang ada.

(Juniradi, 2010). Dari 12 data pengamatan pada lokasi diketahui rata-rata prosentase penyeberangan pada lokasi jalan Kartini didepan lembaga pendidikan Teknokrat adalah 63.42\%. Ini menujukkan bahwa pada lokasi di jalan Kartini tingkat efektifitas penyeberangan masih tergolong tinggi yaitu nilainya terletak diantara 0.60 s.d. 0.80. Untuk tingkat kepercayaan $95 \%$ rata-rata prosentase volume penyeberang jalan pada lokasi jalan kartini ada diantara $50.64 \%$ dan $76.18 \%$. Pada hari yang berbeda didapatkan hasil bahwa dari12 data pengamatan pada lokasi diketahui rata-rata prosentase penyeberangan pada lokasi jalan Kartini didepan lembaga pendidikan Teknokrat adalah $93.25 \%$. Ini menujukkan bahwa pada lokasi di jalan Kartini tingkat efektifitas penyeberangan masih tergolong sangat tinggi yaitu nilainya terletak diantara 0.80 s.d. 0.10. Untuk tingkat kepercayaan $95 \%$ rata-rata prosentase volume penyeberang jalan pada lokasi jalan kartini ada diantara $72.39 \%$ dan $114.11 \%$

(Junaedi, 2011) Volume pedestrian menyeberang dan tidak menyeberang lebih besar terjadi pada hari minggu dengan nilai 26.782 pedestrian dan jalan Kartini memberikan sumbangan nilai terbesar yaitu 16.211 pedestrian. 2. Kecepatan pejalan kaki antara pria dan wanita memiliki perbedaan dengan nilai kecepatan rata-rata pria $49,10 \mathrm{~m} / \mathrm{menit}$ dan kecepatan rata-rata wanita yaitu $47,36 \mathrm{~m} / \mathrm{menit}$

(Junaedi, 2013) Survei yang dilakukan terhadap 250 pejalan kaki yang menyeberang jalan menunjukkan hasi diantaranya bahwa nilai maksimum kecepatan dari pejalan kaki adalah 1,65 meter/detik, nilai ini terjadi pada kasus dimana pejalan kakinya adalah anak muda dimana dapat berjalan cepat dan kadang berlari. Dari hasil survei yang dilakukan juga didapatkan bahwa kecepatan minimum pejalan kaki adalah 0,95 meter/detik. Kecepatan minimum ini ditemukan pada pejalan kaki yang telah memiliki usia lanjut. Didapatkan kecepatan rata-rata pejalan kaki pada saat menyeberang jalan adalah 1,28 meter/detik. Pada umumnya jika diambil rerata, sebesar $10 \%$ kecepatan pejalan kaki paling lambat adalah $0,62 \mathrm{~m} / \mathrm{det}$, dan rata-rata jumlah pejaan kaki yang tidak bisa menyeberang jalan pada saat kendaraan berhenti adalah $6,32 \%$

\section{Resiko Pejalan Kaki}

Telah kita ketahui bahwa pejalan kaki sangat rentan mengalami kecelakaan saat sedang berjalan di trotoar maupun saat sedang menyebrang jalan. Hal ini menjadi sangat penting karena menyangkut keselamatan, untuk itu perlu adanya sebuah strtegi yang memberikan kebijakan dengan memperhatikan hak pejalan kaki. Keamanan 
pejalan kaki bisa diwujudkan melalui penyediaan fasilitas pejalan kaki yang bisa melindungi pejalan kaki dan memberikan keamanan bagi pejalan kaki

Dalam penelitiannya pada tahun 2012, Noviyanti melakukan identifikasi terhadap titik rawan kecelakaan dengan hasil lokasi black spot tertinggi berada di Yos Sudarso dengan angka kecelakaan sebesar 1,18 dan Jalan Sukarno Hatta sebesar 0,35. Berdasarkan lokasi kecelakaan, yang paling banyak terjadi berada di depan kantor atau perusahaan dengan jumlah korban terbanyak pada tahun 2011 yaitu 9 orang meninggal dunia, 7 orang Iuka, dan 21 orang Iuka ringan. Lokasi kecelakaan terbesar selanjutnya terjadi di depan fasilitas umum. Tipe kecelakaan yang memiliki angka tertinggi adalah meninggal dunia dengan jenis kecelakaan depan depan yang didasarkan pada data dalam kurun waktu 5 tahun terakhir. Sebesar 6\% dari total korban, semua Vulnerable Road User (VRU) yang terlibat tercatat meninggal dunia.

Dari kajian ini diberikan rekomendasi terbaik bagi vulnerable road user yaitu dengan adanya fasilitas khusus untuk Vulnerable Road User (VRU) seperti fasilitas pejalan kaki dan penyeberangan jalan. Data yang diperoleh mempresentasikan bahwa tungkat kematian yang terjadi pada pejalan kaki masih sangat tinggi. Masih tingginya tingkat fatalitas yang terjadi pada pejalan kaki mendorong dan mendukung untuk adanya pengembangan dan peningkatan kualitas serta perbaikan untuk fasilitas pejalan kaki.

\section{Fasilitas Pejalan Kaki}

Trotoar bukan satu satunya fasilitas yang diperuntukkan bagi pejalan kaki. Jembatan penyebrangan atau terowongan penyebrangan juga merupakan fasilitas yang diperuntukan bagi pejalan kaki. Bahkan saat ini fasilitas penyebrangan bagi pejalan kaki telah berkembang dengan adanya countdown signal yang dapat dipasang pada simpang bersinyal.

(Juniardi, 2010). Kebutuhan akan fasilitas pejalan kaki berupa fasilitas penyebrangan telah diteliti oleh Junaidi dengan hasil dimana jumlah rata-rata pejalan kaki pada jam sibuk adalah 78,00 $<1100$ pejalan kaki/jam. sehingga dapat ditarik kesimpulan fasilitas yang direkomendasikan menggunakan fasilitas penyeberangan Pelican dengan pelindung. Jumlah pejalan kaki yang telah di survei di Bandar Lampung pada hari Rabu tanggal 2 Juni 2010 jumlah rata-rata pejalan kaki pada jam sibuk adalah 128,25 pejalan kaki/jam < 1100 pejalan kaki/jam dan volume kendaraan 6.306 kendaraan/jam > 750 kendaraan/jam, PV2 > 2 x 108 sehingga dapat ditarik kesimpulan bahwa fasilitas yang direkomendasikan menggunakan fasilitas penyeberangan Pelican dengan pelindung.

Dalam penelitian yang dilakukan Istaslama Bakri tahun 2013 yang berjudul Alih Fungsi Trotoar Menjadi Tempat Pedagang Kaki Lima Jalan Z.A. Pagar Alam Bandar Lampung memperlihatkan adanya perubahan fungsi trotoar yang diperuntukkan bagi pejalan kaki menjadi berbagai fungsi lain yang ditunjukkan pada Tabel 1.

Tabel 1. Jumlah Bentuk Alih Fungsi

\begin{tabular}{llccc}
\hline \multirow{2}{*}{ No } & \multicolumn{2}{c}{ Bentuk Alih Fungsi } & \multicolumn{3}{c}{ Jumlah } \\
& & Kanan & Kiri & Total \\
\hline 1 & Pedagang Kaki Lima & 28 & 28 & 56 \\
2 & Parkir & 26 & 9 & 35 \\
3 & Atribur Reklame & 19 & 14 & 33 \\
4 & Rambu Lalu lintas & 14 & 21 & 35 \\
\hline$\quad$ Total & 88 & 74 & 162 \\
\hline
\end{tabular}

(Bakri, 2013) Pengamatan dilakukan dengan melakukan survei terhadap trotoar yang terlihat memiliki bentuk alih fungsi. Pengamatan diawali dengan melakukan penelusuran trotoar dari Tanjung Karang hingga Rajabasa. Panjang Trotoar yang ditelusuri adalah 4,4 Km. Penelusuran dilakukan dengan mengamati sisi kanan dan kiri trotoar. Pengamatan yang dilakukan dengan melakukan penelusuran menghasilkan data mengenai alih 
fungsi yang terjadi pada sisi kanan dan kiri trotoar sepanjang 4,4 Km ini dengan total 162 titik yang mengalami alih fungsi. Dari keseluruhan data bentuk alih fungsi paling banyak terjadi akibat adanya aktivitas pedagang kaki lima yaitu sebanyak 56 titik. Bentuk alih fungsi lainnya terjadi akibat parkir yaitu sebanyak 35 titik, rambu lalu lintas sebanyak 35 titik dan akibat atribut reklame sebanyak 33 titik.

(Bakri, 2013) Dari pengamatan bentuk alih fungsi yang terjadi pada sisi kanan kiri trotoar sepanjang 4,4 $\mathrm{Km}$ bentuk alih fungsi yang tertinggi adalah akibat pedagang kaki lima. Keseluruhan luas trotoar yang diamati adalah $15.840 \mathrm{~m} 2$. Dari keseluruhan luas trotoar bentuk alih fungsi trotoar akibat aktifitas pedagang kaki lima adalah seluas 251,9 atau setara dengan 1,6\% dari keseluruhan luas trotoar yang diamati. Luas keseluruhan lahan trotoar yang mengalami bentuk alih fungsi akibat pedagang kaki lima dihitung dari total jumlah luas lahan trotoar yang digunakan oleh setiap pedagang sebagai tempat berdagang. Luas bagian trotoar yang digunakan oleh masingmasing pedagang kaki lima berbeda-beda. Untuk keseluruhan luas trotoar yang diamati didapatkan dari pengukuran dua kali panjang jalan sejauh 4,4 km dan dikalikan lebar efektif trotoar untuk pejalan kaki sebesar 1,8 $\mathrm{m}$. Sehingga didapatkan hasil $15.840 \mathrm{~m} 2$.

(Junaedi, 2014).Telah dilakukan penelitian dengan mengamati 250 pejalan kaki yang melakukan aktivitas baik menyebrang maupun berjalan kaki di simpang bersinyal. Hasil pengamatan menunjukkan bahwa terdapat 16 orang atau sekitar $6,4 \%$ pejalan kaki yang mengalami incomplete crossing. Untuk menanggulangi permasalahan incomplete crossing yang dihadapi oleh pejalan kakai diperlukan pemasangan peralatan countdown signal yang berfungsi untuk meningkatkan keamanan dan kenyamanan pejalan kaki. Pemasangan alat countdown signal tersebut harus disesuaikan dengan waktu yang dibutuhkan bagi pejalan kaki untuk menyelesaikan aktivitas berjalan atau menyebrang disimpang tersebut. Waktu yang ideal adalah 15 detik. Saat ini pengaturan lampu lalulintas yang ada di simpang yang diamati tidak memberikan waktu kepada pejalan kaki untuk menyeberang jalan sehingga perlu adanya pengaturan ulang pada lampu lalu lintas dengan mengakomodir waktu untuk penjalan kaki dalam menyeberang jalan

(Junaedi, 2011) Rasio antara lebar eksisting, lebar dibutuhkan, dan lebar KepMen yaitu 0,8 m, 1,9 m dan 4 $\mathrm{m}$. Nilai rasio V/C untuk trotoar dengan lebar eksisting yaitu 0,253 , V/C untuk trotoar dengan lebar dibutuhkan 0,108 , dan V/C untuk trotoar dengan lebar KepMen 0,051. Maka tingkat pelayanan yg didapat yaitu untuk trotoar dengan lebar eksisting $\mathrm{C}$, untuk trotoar dengan lebar dibutuhkan B, dan untuk trotoar dengan lebar KepMen A. Nilai tingkat pelayanan trotoar berdasarkan KepMen memiliki nilai tingkat pelayanan paling baik dibanding berdasarkan dua lebar trotoar lainnya. Nilai tingkat pelayanan fasilitas pejalan kaki dari tujuh titik lokasi yang disurvei, menunjukkan fasilitas Penyeberangan di Jalan Kartini berupa jembatan penyeberangan memiliki nilai tingkat pelayanan terendah yaitu "F". Tingkat pelayanan zebra cross pada hari Minggu dari perhitungan didapat V/C 0,028 dengan nilai LOS A, maka tingkat pelayanan zebra cross baik meskipun kondisinya sudah mulai memudar. Dari hasil survei kuesioner didapat bahwa pejalan kaki sebagai pengguna fasilitas pejalan kaki merasa fasilitas yang ada masih kurang memberikan keamanan dan kenyamanan baik untuk fasilitas trotoar maupun jembatan penyeberangan meskipun dari hasil analisa didapat bahwa rata-rata fasilitas yang ada memiliki tingkat pelayanan yang baik

\section{SIMPULAN}

Tingginya volume pejalan kaki menunjukan masih tingginya permintaan pejalan kaki, fasilitas yang tersedia saat ini belum dapat memenuhi kebutuhan bagi pejalan kaki baik fasilitas pejalan kaki berupa trotoar maupun fasilitas penyebrangan berupa jembatan penyebrangan, terowongan penyebrangan dan countdown signal pada simpang bersinyal. Fasilitas pejalan kaki yang saat ini tersedia masih belum optimal sehingga pejalan kaki masih belum mendapatkan kenyamanan dan keamanan saat melakukan aktivitas berjalan kaki baik menyebrang maupun berjalan di sisi jalan. Perlu adanya kajian yang lebih dalam melihat kebutuhan dan urgensi dari fasilitas pejalan kaki. Serta tantangan yang dihadapi untuk mewujudkan keselamatan pejalan kaki khusunya dikota bandar lampung.

\section{UCAPAN TERIMA KASIH} penelitian ini

Penulis menyampaikan ucapan terima kasihnya kepada para peneliti yang karya nya digunakan dalam 


\section{REFERENSI/DAFTAR PUSTAKA}

Bakri,Istaslama. Asyik, Buchori, Utami, Rachma Kurnia Sri. (2013) Alih Fungsi Trotoar Menjadi Tempat Pedagang Kaki Lima Jalan Z.A. Pagar Alam Bandar Lampung. Jurnal Penelitian Geografi. Vol 2 No. \% (2014), 1-12

Damsere-Derry J, et al. (2010) Pedestrians' injury patterns in Ghana. Accident Analysis \& Prevention, 42: 1080-1088.

Departemen Pekerjaan Umum. 1990. No.007/T/BNKT/1990:Petunjuk Peren canaan Trotoar.

Departemen Pekerjaan Umum Direktorat Jendral Bina Marga dan Direktorat Pembinaan Jalan Kota.

Global status report on road safety 2013: supporting a decade of action. Geneva, World Health Organization, 2013.

Junaedi, Tas'an.(2010). Analisis Kinerja Dan Tingkat Pelayanan Fasilitas Pedestrian Pada Pusat Pertokoan Di Bandar Lampung. Jurnal Rekayasa. Vol 14 No. 3 Desember 2010, 169-178, ISSN: 0852-7733

Junaedi, Tas'an.(2014).Analisis Keselamatan Pejalan Kaki Pada Simpang Bersinyal.Jurnal Rekayasa.Vol 18 No. 3 Desember 2014, 217-226, ISSN: 0852-7733

Juniardi, Juniardi.(2010) Analisis Kebutuhan Fasilitas Penyeberangan Dan Perilaku Pejalan Kaki Menyeberang Di Ruas Jalan Kartini Bandar Lampung. Jurnal Teknik Sipil Bandar Lampung, vol. 1, no. 1, 31 Oct. 2010.

Noviyanti, (2012). Identifikasi Kecelakaan pada Lokasi Black Spot di Kota Bandar Lampung . Warta Penelitian Perhubungan, Vol 24. No. 4 th 2012, 391-411.http://doi.org/ 10.25104/warlit.v24i4.1021

Pedestrian safety: a road safety manual for decision-makers and practitioners, World Health Organization, 2013. 